Notre Dame Law School

NDLScholarship

Journal Articles

Publications

2007

\title{
Pluralism, Dialogue, and Freedom: Professor Robert Rodes and the Church-State Nexus
}

Richard W. Garnett

Notre Dame Law School, rgarnett@nd.edu

Follow this and additional works at: https://scholarship.law.nd.edu/law_faculty_scholarship

Part of the First Amendment Commons, and the Religion Law Commons

\section{Recommended Citation}

Richard W. Garnett, Pluralism, Dialogue, and Freedom: Professor Robert Rodes and the Church-State Nexus, 22 J. L. \& Religion 503 (2006-2007).

Available at: https://scholarship.law.nd.edu/law_faculty_scholarship/725

This Article is brought to you for free and open access by the Publications at NDLScholarship. It has been accepted for inclusion in Journal Articles by an authorized administrator of NDLScholarship. For more information, please contact lawdr@nd.edu. 


\section{PLURALISM, DIALOGUE, AND FREEDOM: PROFESSOR ROBERT RODES AND THE CHURCH-STATE NEXUS}

\section{Richard W. Garnett}

President George H.W. Bush caused a few chuckles-and, more than likely, a few groans-when, out on the trail during the 1988 presidential campaign, he recalled being shot down over the South Pacific in World War II:

Was I scared floating in a little yellow raft off the coast of an enemy-held island, setting a world record for paddling? Of course I was. What sustains you in times like that? Well, you go back to fundamental values. I thought about Mother and Dad and the strength I got from them-and God and faith and the separation of Church and State.

Mother, Dad, God, faith—“and the separation of church and state." This train of thought probably strikes us as a bit absurd. And yet, it is entirely American. That "God" and "faith" could not be invoked by the future President, as "fundamental values," without the addition of "the separation of church and state" speaks volumes about how we Americans think about the content and implications of religious freedom, our "first freedom." Indeed, Professor Daniel Dreisbach observed not long ago that "[n]o metaphor in American letters has had a greater influence on law and policy than Thomas Jefferson's 'wall of separation between church and state.",3 For many Americans, this metaphor supplies-in Professor Philip Hamburger's words-the

* John Cardinal O'Hara, C.S.C., Associate Professor of Law, University of Notre Dame, Notre Dame, Indiana. I am grateful to Kyle Duncan, Bob Rodes, Nelson Tebbe, Nicole Garnett, Kathleen Brady, and Rob Vischer for their comments and suggestions. Thanks are also due to Professor Rodes and his brilliant wife Jeanne for their friendship and inspiration.

1. Cullen Murphy, War Is Heck, Wash. Post A21 (Apr. 8, 1988). See also David Shribman, Bush, Dole Butt Heads a Little Harder as Top Contenders Hone Tough Images, Wall St. J. 54 (Jan. 11, 1988).

2. Remarks at James Madison High School in Vienna Virginia, 2 Pub. Papers 1075, 1076 (July 12, 1995); see also e.g. Thomas J. Curry, The First Freedoms: Church and State in America to the Passage of the First Amendment (Oxford U. Press 1986); Michael W. McConnell, Why Is Religious Liberty the "First Freedom"?, 21 Cardozo L. Rev. 1243 (2000).

3. Daniel L. Dreisbach, Origins and Dangers of the "Wall of Separation" Between Church and State, 35 Imprimis 1, 1 (Oct. 2006). 
"authoritative interpretation" of the First Amendment's Religion Clauses; and "vast numbers of [us] have come to understand [our] religious freedom in terms of Jefferson's phrase. As a result, Jefferson's words often seem more familiar than the words of the First Amendment itself." $" 4$

The idea of church-state "separation" and the image of a "wall" are at the heart of nearly every citizen's and commentator's thinking about law and religion, and about faith and public life..$^{5}$ Unfortunately, the inapt image often causes great confusion about the important idea. Certainly, as then-Justice William Rehnquist once observed, the "wall" metaphor has "proved all but useless as a guide to sound constitutional adjudication." Of course, to say this is not to question the importance to religious and political freedom of distinguishing the institutions and authorities of religion from those of government. Nor is it to deny that this distinction was important to many of those who drafted and ratified the First Amendment, or to doubt its importance to sound constitutional doctrine. ${ }^{7}$ It is to worry, though-and to regret-that what should be regarded as an important feature of religious freedom under constitutionally limited government too often serves simply as a slogan, and is too often employed as a rallying cry, not for the distinctiveness and independence of religious institutions, but for the marginalization and privatization of religious faith. ${ }^{8}$

How, then, should we understand church-state "separation"? What is the connection between separation, well understood, and religious freedom? What is the place, or role, of religious faith, believers, and

4. Philip Hamburger, Separation and Interpretation, 18 J. L. \& Pol. 7, 7 (2002). See also Philip Hamburger, Separation of Church and State 1 (Harv. U. Press 2002) ("Jefferson's words seem to have shaped the nation.") [hereinafter Hamburger, Church and State].

5. See e.g. Dreisbach, supra n. 3, at 1 ("For many Americans, this metaphor has supplanted the actual text of the First Amendment to the U.S. Constitution, and it has become the locus classicus of the notion that the First Amendment separated religion and the civil state, thereby mandating a strictly secular polity."); Hamburger, Church and State, supra n. 4, at 1 ("Jefferson's phrase... provides the label with which vast numbers of Americans refer to their religious freedom.").

6. Wallace v. Jaffree, 472 U.S. 38, 107 (1985) (Rehnquist, J., dissenting).

7. See e.g. John Witte, Jr., Religion and the American Constitutional Experiment: Essential Rights and Liberties 48-50 (Westview Press 2000) (noting that "separation of church and state guarantees 'ecclesiastical purity and liberty'-the independence and integrity of the internal processes of religious bodies").

8. Cf. e.g. John Witte Jr., God's Joust, God's Justice: Law and Religion in the Western Tradition 160-162 (William B. Eerdmans Publg. Co. 2006) (discussing the "separation and cooperation" of church and state in American Puritan thought and practice); Hamburger, Church and State, supra n. 4, at 2-3 (contrasting "a differentiation or distinction between church and state" with "something more dramatic - a distance, segregation, or absence of contact between church and state"). 
institutions in the political community governed by our Constitution? With respect to these and so many other interesting and important questions, the work of Professor Robert Rodes has been and remains a help, a challenge, and an inspiration.

Professor Rodes is my teacher, colleague, and friend. It is a gift and a pleasure working with and learning from him at the Notre Dame Law School. He welcomed me warmly when I arrived, as a new law teacher in 1999, and he has guided and encouraged me ever since. Certainly, his "blood is in the bricks" of the community of learning and lawyers which he has served and shaped for five decades. His generosity, charity, curiosity, and decency have been and are a blessing and an inspiration to so many scholars, students, lawyers, and clients. He has made the Law School and its Christian mission of scholarship and formation his vocation, and all of us who are connected to or care about that mission owe him our respect and thanks.

It is particularly appropriate that the Journal of Law and Religion is honoring Professor Rodes's work and achievements. For half a century, he has written thoughtfully, engagingly, and provocatively about an imposingly broad and diverse range of subjects: ${ }^{9}$ legal ethics ${ }^{10}$ and liberation theology, ${ }^{11}$ symbolic logic ${ }^{12}$ and symbolist jurisprudence, ${ }^{13}$ chastity ${ }^{14}$ and the Church of England, ${ }^{15}$ Catholic universities ${ }^{16}$ and canon law, ${ }^{17}$ and-of course-workman's compensation for maritime employees. ${ }^{18}$ And, running through this entire body of work has been a

9. See generally Thomas L. Shaffer, The Christian Jurisprudence of Robert E. Rodes, Jr., 73 Notre Dame L. Rev. 737 (1998).

10. See e.g. Robert E. Rodes, Jr., Forming an Agenda-Ethics and Legal Ethics, 77 Notre Dame L. Rev. 977 (2002).

11. See e.g. Robert E. Rodes, Jr., Pilgrim Law (U. Notre Dame Press 1998) [hereinafter Rodes, Pilgrim Law]; Robert E. Rodes, Jr., Law and Liberation (U. Notre Dame Press 1986).

12. See e.g. Robert E. Rodes, Jr. \& Howard Pospesel, Premises and Conclusions: Symbolic Logic for Legal Analysis (Prentice Hall 1997).

13. See e.g. Robert E. Rodes, Jr., A Prospectus for a Symbolist Jurisprudence, 2 Nat. L. Forum 88 (1957).

14. See e.g. Robert E. Rodes, Jr., On Law and Chastity (Carolina Academic Press 2006).

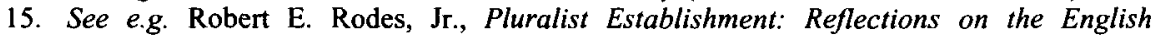
Experience, 12 Cardozo L. Rev. 867 (1991).

16. See e.g. Robert E. Rodes, Jr., Catholic Universities and the New Pluralism, in The Challenge and Promise of a Catholic University 305 (Theodore M. Hesburgh ed., U. Notre Dame Press 1994).

17. See e.g. Robert E. Rodes, Jr., The Canon Law as a Legal System-Function, Obligation, and Sanction, 9 Nat. L. Forum 45 (1964).

18. See e.g. Robert E. Rodes, Jr., Workmen's Compensation for Maritime Employees: Obscurity in the Twilight Zone, 68 Harv. L. Rev. 637 (1955). 
sustained conversation about law and religion, faith and politics, church and state. ${ }^{19}$

Professor Rodes's thinking about these matters is rich, prescient, and distinctive. I could not begin to do it justice here, and there is no point in pretending that this is merely because of space constraints. Indeed, as a relatively junior law teacher who also studies and writes about law and religion, I am humbled, and a bit intimidated, by the opportunity to address and engage the contributions of a scholar whom I first encountered through an approving citation in John Courtney Murray's landmark 1960 book, We Hold These Truths, ${ }^{20}$ and whose first published article is a comment on what were then the recently decided Everson and McCollum decisions. ${ }^{21}$

That said, this essay is an appreciation, interpretation, and application of Professor Rodes's church-state work. In particular, it contrasts the church-state "nexus" that he has explored and explained with Jefferson's misleading but influential "wall" metaphor. After identifying and discussing a few of the more salient features of this "nexus," it closes with some thoughts about how the leading themes in Rodes's law-and-religion writing can help us better understand and negotiate one of today's most pressing religious freedom problems. But first, a brief review of how the "wall" image came to occupy the churchstate field will set the scene for the discussion that follows.

II.

As Professor John Witte has noted, the "wall of separation" has, in public law and in public discourse, proved far more "serpentine"--both in the sense of winding and twisting, and in the Edenic sense of "seductively simple" - than many who invoke it appreciate. ${ }^{22}$ Where did

19. See Shaffer, supra n. 9, at 757 ("Much of Rodes's scholarship has been in the field American legal academics call "the law of church and state.").

20. In a discussion of the "School Question," Murray observed that

[t] he public school system still, of course, merits strong defense, the more so as it gradually succeeds in relating itself realistically to the religious realities of the United

States. But the old dual pattem is out of touch with contemporary socio-religious reality. The notion of "public education" as meaning a unitary and monolithic school system which singly and alone is entitled to public support has been rightly called (by Mr. Robert E. Rodes, Jr.) "an aberration in the general picture of our society, which is pluralistic."

John Courtney Murray, We Hold These Truths: Catholic Reflections on the American Proposition 147 (Sneed \& Ward 1960).

21. Robert E. Rodes, Jr., Religious Education and the Historical Method of Constitutional Interpretation-A Review Article, 9 Rutgers L. Rev. 682 (1955).

22. Witte, supra n. 8, at 209. 
it come from?

Certainly, the idea of a distinction between the church and the political authorities, between what Calvin called the "spiritual kingdom" and the "political kingdom," between believers and the world, between the City of God and the City of Man, is much older than the American Constitution and long predates those Enlightenment thinkers widely thought to have conceived it. ${ }^{23}$ In Professor Witte's words, although "[s]eparation of Church and state is often regarded as a distinctly American and relatively modern invention[,]" it is, in fact, "an ancient Western teaching rooted in the Bible." ${ }^{24}$ Christ's followers were taught to "repay to Caesar what belongs to Caesar and to God what belongs to God"; 25 Pope Gelasius instructed the Emperor Anastasius that "[t]here are indeed ... two powers by which this world is chiefly ruled"; 26 Pope Boniface VIII identified "two swords-a spiritual ... and a temporal" (and claimed them both); ${ }^{27}$ and Roger Williams contrasted the "Garden of the Church and the Wilderness of the world."28 And so on. ${ }^{29}$

For present purposes, though-that is, for the purpose of tracing the importation into the Constitution of a "wall of separation" between church and state-we can begin the story in October of 1801. The Baptist Association of Danbury, Connecticut wrote to President-elect Thomas Jefferson, congratulating him on his election to the "chief Magistracy in the United States." 30 In their letter, no doubt hoping to ingratiate themselves and their cause to the new President, the Danbury Baptists trumpeted their disagreement with Jefferson's Congregationalist and Federalist opponents who had energetically attacked and scorned

23. See generally e.g. Carl H. Esbeck, Dissent and Disestablishment: The Church-State Settlement in the Early American Republic, 2004 BYU L. Rev. 1385, 1395-1447.

24. Witte, supra n. 8, at 210. See generally id. at 210-224.

25. Matt 22:21 (all Biblical citations are taken from the New Am. Bible). The next verse records that when the Pharisees heard this, "they were amazed, and leaving him they went away."

26. The text of this letter is available through the Internet Medieval Source Book, Medieval Sourcebook: Gelasius I on Spiritual and Temporal Power, 494, http://www.fordham.edu/ halsall/source/gelasius I.html (accessed Dec. 20, 2006).

27. Boniface VIII, Unam Sanctum (1302), reprinted in Medieval Worlds 77, 77 (Roberta Anderson \& Dominic Aidan Bellenger eds., 2003).

28. Roger Williams, Mr. Cotton's Letter Lately Printed, Examined and Answered (1644), reprinted in 1 The Complete Writings of Roger Williams 392 (Russell \& Russell 1963).

29. See generally e.g. Richard W. Garnett, The Freedom of the Church, 4 J. Cath. Soc. Thought 59 (2007).

30. Letter from the Danbury Baptist Association to Thomas Jefferson (Oct. 7, 1801) (on file with the Thomas Jefferson Papers Manuscript Division, Library of Congress, Washington, D.C.), http://baptiststudiesonline.com/wp-content/uploads/2007/02/danbury-letter-to-jefferson.pdf (accessed Mar. 9, 2007). See generally e.g. Daniel L. Dreisbach, Sowing Useful Truths and Principles: The Danbury Baptist, Thomas Jefferson, and the Wall of Separation, 39 J. Church \& St. 455 (1997). 
him during the 1800 campaign as "an enemy of religion[,] Law \& good order," and noted also that their own "[s]entiments are uniformly on the side of Religious Liberty[.]"31 For the Baptists, the letter explained to the President, as for many other dissenters from Founding-era religious establishments,

religion [is] an essentially private matter between an individual and his God. No citizen, they reasoned, ought to suffer civil disability on account of his religious opinions. The legitimate powers of civil government reach actions, but not opinions. ${ }^{32}$

Jefferson, of course, was "keenly aware of the political implications of his pronouncement on a delicate church-state issue," and he replied a few months later in a well considered and carefully crafted letter of his own, one that reflected not just his views about the First Amendment and his frustration with the attacks of his political enemies, but also his own fierce anti-clericalism. ${ }^{33} \mathrm{He}$ wrote, in the letter's key and famous passage:

Believing with you that religion is a matter which lies solely between Man \& his God, that he owes account to none other for his faith or his worship, that the legitimate powers of government reach actions only, $\&$ not opinions, I contemplate with sovereign reverence that act of the whole American people which declared that their legislature should "make no law respecting an establishment of religion, or prohibiting the free exercise thereof," thus building a wall of separation between Church \& State. ${ }^{34}$

Jefferson's letter was published in Massachusetts, shortly after it was received, but was then forgotten for a half-century. ${ }^{35}$ (Indeed, the Danbury Baptists themselves appear to have been reluctant to publicize the letter or its contents. $)^{36}$ It does not appear that Jefferson ever

31. Letter from the Danbury Baptist Association, supra n. 30.

32. Daniel L. Dreisbach \& John D. Whaley, What the Wall Separates: A Debate on Thomas Jefferson's “Wall of Separation" Metaphor, 16 Const. Comment 627, 631 (1999).

33. Id. at 632, 631 ("The surviving manuscripts reveal that Jefferson's reply was written with meticulous care and planned effect."). The letter's political context and the motives and concerns that probably shaped it are described in James H. Hutson, Thomas Jefferson's Letter to the Danbury Baptists: A Controversy Rejoined, 56 William \& Mary Q. 775 (1999). See also Hamburger, Church and State, supra n. 4, at 144-161 (noting that Jefferson "elevated anticlerical rhetoric to constitutional law").

34. Letter from the Danbury Baptist Association, supra n. 30.

35. James Hutson, "A Wall of Separation": FBI Helps Restore Jefferson's Obliterated Draft, 57 Lib. Cong. Info. Bull. 136 (June 1998). Hamburger, Church and State, supra n. 4, at 162 (" $[\mathrm{H}]$ is epistle was not widely published or even noticed."). Professor Dreisbach has noted that Jefferson's Letter to the Danbury Baptists first received wide circulation in 1853, when it was included in an edition of his works. See Dreisbach, supra n. 30.

36. Hamburger, Church and State, supra n. 4, at 163-180 (contrasting the Baptists' views 
employed the "wall of separation" image again. ${ }^{37}$

As Professor Hamburger has explained, the idea of "separation" between church and state was, during most of the nineteenth century, not so much a Jefferson-inspired constitutional doctrine as an anti-Catholic rhetorical weapon. ${ }^{38}$ However, in the 1879 case of Reynolds $v$. United States, a case involving the bigamy prosecution of a Mormon and one of the Supreme Court's first major decisions interpreting the First Amendment's Religion Clauses, the Justices quoted Jefferson's letter to the Danbury Baptists, invoked the "wall" metaphor, and reported that Jefferson's response "may be accepted almost as an authoritative declaration of the [Clauses'] scope and effect ....,"39

The Court did not return to the metaphor for almost seventy years. Then, in the landmark 1947 case, Everson v. Board of Education, Justice Black went beyond the Reynolds ruling and announced that the First Amendment's Establishment Clause constrains not only the actions of Congress, but also those of state and local officials. ${ }^{40}$ Although a narrow majority of the Court declined to rule that a New Jersey law allowing reimbursements to parents for money spent on bus transportation to parochial schools violated the First Amendment, Justice Black followed Reynolds in giving Jefferson's letter, and the "wall," controlling, canonical weight. After a lengthy, if misguided, ${ }^{41}$ account of the Establishment Clause's history, context, and meaning, Justice Black summed up in this way:

In the words of Jefferson, the clause against establishment of religion by law was intended to erect "a wall of separation between Church and State." 42 That wall must be kept high and impregnable. We could not approve the slightest breach. ${ }^{43}$

relating to religious freedom with Jefferson's version of separationism).

37. Dreisbach \& Whaley, supra n. 32, at 635.

38. See generally Hamburger, Church and State, supra n. 4. See also Witte, supra n. 8, at 231 ("[T]he principle of separation of church and state became one of the strong new weapons in the anti-Catholic arsenal."). Cf. Douglas Laycock, The Many Meanings of Separation, 70 U. Chi. L. Rev. 1667, 1679 (2003) (agreeing that, in the early-to-mid 19th century, "separation took on a new meaning, roughly but fairly summarized as restricting Catholic influence[,]" but insisting also that "separation" has and has long had many meanings).

39. Reynolds v. U.S., 98 U.S. 145, 164 (1878).

40. Everson v. Bd. of Educ. of Ewing Township, 330 U.S. 1 (1947).

41. See e.g. John Courtney Murray, Law or Prepossessions?, 14 L. \& Contemp. Probs. 23, 40 (1949) ("The absolutism of [Everson] ... is unsupported, and unsupportable, by valid evidence and reasoning-historical, political, or legal-or on any sound theory of values, religious or social."). See generally e.g. Hamburger, Church and State, supra n. 4, at 454-478.

42. Everson, 330 U.S. at 16.

43. Id at 18. 
(Some of Justice Black's critics, though-fellow separationistsprotested that he had done just that.) ${ }^{44}$

A lot has changed in constitutional law-and, in particular, in the understanding and application of the Religion Clauses-since 1947. Still, and even though many of these changes have been in a non-strictseparationist direction, ${ }^{45}$ what Chief Justice William Rehnquist once called Jefferson's "misleading metaphor" ${ }^{46}$ has become deeply and-it appears-indelibly ingrained in Americans' thinking about church-state relations and religious freedom. ${ }^{47}$ As the Court has moved in recent years from a no-aid-to-religion understanding of the First Amendment to a more accommodating view, it has been impossible to avoid warnings that the "wall of separation" is being lowered, knocked down, weakened, or breached. ${ }^{48}$ Even as First Amendment doctrine moves in the direction of neutral treatment by government of religious expression and activity, ${ }^{49}$ it is often charged that religiously motivated or inspired arguments, claims, expression, and activism are-if brought to bear in public discussions or upon political questions-inconsistent with our commitment to church-state separation. Such overheated warnings and misplaced charges can inspire errors in response, as when, in August of 2006, Rep. Katherine Harris, a candidate for the United States Senate known primarily for her role in Florida's 2000 presidential election, announced that the separation of church and state is a "lie we have been told" to keep religious believers out of politics and public life. ${ }^{50}$

It seems, then, that we are nearly as confused about separation as we are attached to it. There are good reasons, however, for wanting to get church-state separation right. We should neither embrace nor war against a mistaken version of the idea. After all, as Pope Benedict XVI

44. See Hamburger, Church and State, supra n. 4, at 463-472; John T. McGreevy, Catholicism and American Freedom: A History 183-186 (W.W. Norton \& Co. 2003).

45. See e.g. Ira C. Lupu, The Lingering Death of Separationism, 62 Geo. Wash. L. Rev. 230 (1994).

46. Wallace, 472 U.S. at 91 ("It is impossible to build sound constitutional doctrine upon a mistaken understanding of constitutional history, but unfortunately the Establishment Clause has been expressly freighted with Jefferson's misleading metaphor for nearly 40 years.").

47. See e.g. Dreisbach \& Whaley, supra n. 32, at 627 ("No word or phrase is associated more closely by Americans with the topic of church-state relations than the "wall of separation between church and state."').

48. See e.g. Zelman v. Simmons-Harris, 536 U.S. 639, 686 (2002) (Stevens, J., dissenting) ("Whenever we remove a brick from the wall that was designed to separate religion and government, we increase the risk of religious strife and weaken the foundation of our democracy.").

49. See e.g. Good News Club v. Milford C. Sch., 533 U.S. 98 (2001); Rosenberger v. Rector \& Visitors U. Va., 515 U.S. 819 (1995). Cf. Locke v. Davey, 540 U.S. 712 (2004).

50. Jim Stratton, Harris' Comments Draw Fierce Reaction, Orlando Sentinel Al (Aug. 26, 2006). 
reaffirmed last Christmas in his first encyclical letter, God Is Love, church-state separation is crucial. "Fundamental to Christianity," he insisted, "is the distinction between what belongs to Caesar and what belongs to God ... , in other words, the distinction between Church and State ...." This emphasis on distinction is certainly not a call for disengagement by religious believers, communities, or institutions. ${ }^{52}$ In the Pope's view, at least, church and state are "distinct, yet always interrelated." 53

This view seems consonant with American practice and tradition, if not with "wall of separation" rhetoric. As Justice William Douglas wrote, in the Zorach case, the idea that the "separation" of church and state "must be complete and unequivocal" does not and could not mean that "the state and religion [must] be aliens to each other." 54 Similarly, Chief Justice Warren Burger insisted that the "line of separation" is not so much a "wall" as a "blurred, indistinct, and variable barrier ...." In the context of the modern, activist, welfare state, "separation" or "segregation" of church from state-let alone of religion from public life-seems neither possible nor desirable. Such an understanding of "separation," and of the content of religious freedom, simply does not connect with the world we inhabit or with who and what we are. ${ }^{56}$

III.

As I noted at the outset, Professor Rodes in his law-and-religion work does not invoke or rely on the image of a "wall of separation," but works instead with the more nuanced idea of a "church-state nexus."

51. Pope Benedict XVI, God is Love: Deus caritas est 934 (U.S. Conf. Cath. Bishops 2006). See also e.g. Joseph Cardinal Ratzinger, The Salt of the Earth: Christianity and the Catholic Church at the End of the Millennium 240 (Ignatius Press 1997) ("[S]eparation is ultimately a primordial Christian legacy and also a decisive factor for freedom.").

52. Benedict, supra n. 51, at 36 ("The Church ... cannot and must not replace the State. Yet at the same time she cannot and must not remain on the sidelines in the fight for justice.").

53. Id. at 34 .

54. Zorach v. Clauson, 343 U.S. 306, 312 (1952). See also Christopher L. Eisgruber \& Lawrence G. Sager, Religious Freedom and the Constitution 23 (Harv. U. Press 2007) ("Churches-to say nothing of religion in general-can never be wholly separated from the state.... The question that matters is how church and state should mix, not whether they will do so.").

55. Lemon v. Kurtzman, 403 U.S. 602, 614 (1971). See also Lynch v. Donnelly, 465 U.S. 668,673 (1984) ("No significant segment of our society and no institution within it can exist in a vacuum or in total or absolute isolation from all the other parts, much less from government.").

56. For a detailed discussion of the importance of moral anthropology-that is, of claims about who and what we are and why it matters-for our thinking about religious freedom, see e.g. Steven D. Smith, Believing Persons, Personal Believings: The Neglected Center of the First Amendment, 2002 U. Ill. L. Rev. 1233.

57. Robert E. Rodes, Jr., The Last Days of Erastianism-Forms in the American Church- 
A "nexus," according to my dictionary, is a "means of connection; a link or tie." It suggests a relation, even a symbiosis, between two distinct things - neither a collapse of one into the other nor a rigid segregation of the one from the other. The term captures well, then, Rodes's thinking about church, state, and society. As his friend Professor Thomas Shaffer put it, "the foundation of [Rodes's] church-state theory is that the two are so intertwined-so much the remnant of Christendom-that they could not part even if they wanted to."59 This is, Shaffer notes, a "strikingly unique position" in the church-state field. ${ }^{60}$

It is one thing, though, to characterize a relation as involving a "nexus" rather than a "wall"; it is another to flesh out the nature, character, and implications that "nexus" relation. At least three elements of Rodes's understanding and presentation of the church-state nexus are worth highlighting.

\section{A. The "Erastian" and the "High Church"}

The distinction between "Erastian" and "High Church" doctrines, arguments, and institutional forms does a lot of work, and has real explanatory power, in Rodes's writings on the law that governs and shapes the church-state nexus. These two terms' meaning is fleshed out below; in a nutshell, though, "Erastian" suggests cooperation and overlap while "High Church" suggests competition and separation. "[I]n every period," Rodes explains, there has been "a certain enduring tension in the church-state nexus[,]" a tension which reflects, among other things, the fact that the church as a "juridical presence" has, at some times and in some ways, been involved and engaged in the civic, social, and political arenas, "sharing the historical vicissitudes of the day," and, at other times and in other ways, "stood out against all historical developments, semper eadem." This tension manifests itself not only in the lives of Christians, but also in the institutions of church and state, the arrangements between them, and the laws that govern them. ${ }^{62}$ And, Rodes has often suggested, the distinction between the "Erastian" and the "High Church" helps us address, if not to resolve, this tension.

States Nexus, 62 Harv. Theological Rev. 301 (1969).

58. The American Heritage Dictionary of the English Language 1120 (3d ed., Houghton Mifflin 1992).

59. Shaffer, supra n. 9, at 757.

60. Id.

61. Rodes, Pilgrim Law, supra n. 11, at 140-141.

62. Id. at 140 . 
Erastus was a sixteenth-century Swiss theologian "who taught that the church had no proper coercive jurisdiction independent of the civil magistrate." ${ }^{63}$ His name is usually attached to the view that the state is or should be supreme over, and should control, the church. ${ }^{64}$ Rodes's use, however, denotes something slightly, but importantly, different. For Rodes,

[A]ny approach based on a general unity of function between church and state can be called "Erastian." To the extent that Christianity is viewed as a social agenda and a lifestyle for whole peoples, this unity of purpose will indeed exist: there is no reason why the public implementation of such matters should not be in the same hands as other public affairs. Erastianism, properly understood, is not a subordination of religious to secular concerns; rather, it is a placing of religious concerns on the same level with all other concerns of a Christian government. ${ }^{65}$

Putting aside, for now, questions about what position or approach best warrants the "Erastian" name, Rodes's definition is helpful in describing the way "church" and "state" relate, in our society and in others like it. For Rodes, to suggest that the church is not entirely other, and not entirely segregated (or protected) behind a wall, is not to suggest that it is subordinate to or controlled by the state. On the Erastian view,

the institutional church [is] one of a variety of institutions through which a Christian society conforms itself to the will of God.... Erastianism is not to be equated with the totalitarian view that religious institutions are to be subordinated to secular ends. Quite the opposite, it insists that religious ends are to be pursued purposefully and efficiently, just as secular ends are. ${ }^{66}$

63. Id. at 141 .

64. See e.g. Esbeck, supra n. 23 , at 1582, n. 710 (stating that Erastianism involves "complete state supremacy over the church"); Michael W. McConnell, Establishment and Disestablishment at the Founding, Pt. 1: Establishment of Religion, 44 Wm. \& Mary L. Rev. 2105, 2189 (2003) ("The technical term for governmental control over the church in the English tradition is 'Erastianism.'"); Douglas Laycock, Continuity and Change in the Threat to Religious Liberty: The Reformation Era and the Late Twentieth Century, 80 Minn. L. Rev. 1047, 1053 (1996).

65. Robert E. Rodes, Jr., Pluralist Christendom and the Christian Civil Magistrate, 8 Cap. U. L. Rev. 413, 418 (1979) [hereinafter Rodes, Pluralist Christendom]. See also Rodes, Pilgrim Law, supra n. 11, at 141 ("I have extended the term Erastian to cover any view of the church as one of the complex of institutions public and private through which Christians hope to implement an agenda for the whole society in a given time and place.").

66. Rodes, supra n. 57, at 304. See also e.g. Robert E. Rodes, Jr., The Passing of Nonsectarianism: Some Reflections on the School Prayer Case, 38 Notre Dame Law. 115, 130 (1963) [hereinafter Rodes, Passing of Nonsectarianism] (stating that Erastianism "rejects the rigorous duality of the church and state in favor of a unified religiously oriented society, whose religious orientation is the responsibility of its total institutional structure"). 
We might think that Erastian forms and approaches would be quite out of place in a society, like ours, where conversations about religious freedom and church-state relations almost invariably involve appeals to, or invocations of, Jefferson's "wall of separation." In fact, Rodes insists, "the dominant theme in American church-state thinking [is] a kind of free-enterprise Erastianism." That is,

[a]dhering to the basic Erastian insight that views the institutional church as one of the many institutional forms through which a society conforms itself to the will of God, it adds the American free enterprise insight that sees institutional forms as most efficient when freed from the inhibiting presence of government support. ${ }^{68}$

On the other side of the "enduring tension in [our] church-state nexus," contrasting with Erastian arrangements, are "High Church" forms, arguments, and doctrines. Here, Rodes means to evoke not so much the elevated liturgical tastes of Anglo-Catholics as the "vision of the church as standing over against society[,]" and "as an institutional embodiment of the transcendence, the otherness, of God ...."69 The High Church position is that

the church is the institutional expression of what is other-worldly, holy, entitled to reverence. The state must keep hands off the church because the church is sacred: to interfere with it would be sacrilegious. $^{70}$

"High Churchmen," in Rodes's scheme, are those who "insist[] on the internal autonomy of the church under its divinely-appointed ministers;" they "tend[] to present an eschatological witness over against society and to leave it to the Erastian to present a feasible agenda for the society

67. Rodes, supra n. 57, at 304. See also id. at 330 (“[Most churches' day-to-day understanding of what they are about is characterized by an Erastian acceptance of a place among the various institutions by which an overall and traditionally Christian society underwrites the pursuit of happiness by its members.").

68. Id. at 304 .

69. Rodes, Pilgrim Law, supra n. 11, at 141. See also Rodes, supra n. 57, at 305 (explaining that the High Churchman

see[s] the institutional church as standing over against society in general, rather than as constituting one of the institutions through which society in general conforms itself to the will of God.... The High Church attitude tends to point up the shortcomings of society, and to offer the Christian a way of dissociating himself from them, rather than of ameliorating them. In the past, High Churchmanship has sought an institutional witness in forms that express the independence of the church, and her freedom from the corruptions besetting rest of society.

70. Robert E. Rodes, Jr., From Pierce to Nyquist: A Free Church in an Expensive State, in Freedom \& Education: Pierce v. Society of Sisters Reconsidered 47, 52 (Donald P. Kommers \& Michael J. Wahoske eds., Center for Civil Rights, U. Notre Dame L. Sch. 1978). 
to implement."71

In Rodes's view, we in the United States have "not developed forms of [the High Church] kind .... [T] he generally optimistic tone of American society has kept such thinking from gaining a solid place in the institutional witness of any of the main-stream churches."72 What's more,

[t]he American legal structure has also played a part in inhibiting the growth of High Church forms .... [T] he transcendent witness of High Churchmanship is hard to institutionalize in churches none of which can claim a dominant position in the overall society, or, indeed, any position at all beyond what it derives from its constituents.

That said, Rodes has characterized several of the Supreme Court's church-autonomy cases-including, for example, Kedroff v. St. Nicholas Cathedral, ${ }^{74}$ the Hull Memorial case, ${ }^{75}$ and Watson v. Jones ${ }^{76}$-as protecting a "High Church freedom," i.e., the "freedom of ecclesiastical processes to move in an area where secular processes cannot follow . . ..,"77

What's more, several of our more familiar church-state problems have both Erastian and High Church dimensions. For example, we have long exempted churches and their works from secular taxes, in part on the theory that the religious organizations can and do serve "secular purposes" in and through their work. ${ }^{78}$ In so doing, we "recognize the church as one of the institutions through which citizens engage in their harmless or commendable pursuits[,]" and acknowledge "the support and encouragement of such institutions as high on the list of proper functions of government."79 Our thinking and practice, then, could be characterized as "Erastian." At the same time, the legal doctrines and judicial arguments relating to the churches' tax exemptions also have a

71. Rodes, Pluralist Christendom, supra n. 65 , at 418.

72. Rodes, supra n. 57, at 305-306. "On the whole, a general denunciation of the world's ways in America has been left to fringe churches, which form enclaves and mind their own business, rather than bearing witness against the overall society." Id. at 306 . See also Rodes, Passing of Nonsectarianism, supra n. 66, at 131 ("American nonsectarianism was the product of a people bemused with its own potential for secular achievement in the development of a new land.").

73. Rodes, supra n. 57, at 306.

74. 344 U.S. 94 (1952).

75. Presbyterian Church U.S. v. Mary Elizabeth Blue Hull Meml. Presbyterian Church, 393 U.S. $440(1969)$.

76. 80 U.S. 679 (U.S. 1871 ).

77. Rodes, supra n. 57 , at 317.

78. Id. at $317-324$.

79. Id. at 323 . 
"High Church" flavor, insofar as they reflect a view that churches' doctrines and activities are special, untouchable by government, and related to "a dimension of human existence that the Founding Fathers intended to shield from government intervention."

Similarly, both Erastian and High Church themes run through the financial-support and school-funding cases and controversies. ${ }^{81}$ Writing long before the "Faith Based Initiative" was a glimmer in President George W. Bush's eye, Rodes noted the "expanded financial involvement of government in all aspects of public life" and observed that, as part of that involvement, religious and denominational institutions are subsidized in all kinds of ways. ${ }^{82}$ "Needless to say," he observed, "the justification offered for all this support is Erastian. Functions in which the public is interested are supported equally whether or not they are carried out under religious auspices." ${ }^{.83}$ And yet, it has long been and still is argued that "the fact that an otherwise innocuous activity is carried out under religious auspices creates an overriding objection to public support for it . .."84 For many today, as for Madison, it is an "unhallowed perversion of the means of salvation" to "employ Religion as an engine of Civil policy." 85 This, Rodes suggests, is a High Church contention: "If ecclesiastical projects are to be cut off from government funds, it is because they occupy a place in the lives of men where the concerns of secular government cannot follow them."

\section{B. Integral and Pluralist Christendom}

"Christendom" is not a word or idea that fits comfortably within our contemporary debates and discussions about law and religion, church and state. After all, as even a glance at the new-releases table at the local bookstore confirms, many of our leading commentators see "theocracy" on the march and everywhere. ${ }^{87}$ To refer to, let alone to

80. Id.

81. Id. at 324-329.

82. Id. at 324 .

83. Id. at 324-325.

84. Id. at 326.

85. Id . at 327 (quoting and citing Madison's Memorial and Remonstrance).

86. Id. at 328. See also id. at 329 (noting that it is a "central core of High Church ideology that keeps the state out of the church's central concerns, that guards the borders of the kingdom of the individual and his God, that saves the means of salvation from unhallowed perversion").

87. See e.g. Kevin Phillips, American Theocracy: The Perils and Politics of Radical Religion, Oil, and Borrowed Money in the 21st Century (Thorndike Press 2006); Damon Linker, The Theocons: Secular America Under Siege (Doubleday 2006); Michelle Goldberg, Kingdom Coming: The Rise of Christian Nationalism (W.W. Norton 2006). For a critical review of the 
acknowledge the continuing reality and relevance of, "Christendom" will strike many as a first step toward celebrating the Crusades or the Holy Inquisition. And yet, Professor Rodes has long insisted both that Christendom persists and that its persistence need not cause alarm. That is, according to Rodes, one of the characteristics of our church-state nexus - a feature that must be understood for the whole thing to workis that it exists in a particular cultural context, a context of "pluralist Christendom." 88 What does this mean?

Before the conversion of Constantine, Rodes has explained, the Christian church was an "eschatological community," one that "waited confidently for God to bring about the consummation of history," and that "had no agenda whatever for the wider society." 89 Afterward, though, "it was no longer possible for the church to have nothing to say about how the state should be run"; the church was "forced... to develop an agenda for the whole society....."90 The result of this change was-eventually - the "medieval church-state nexus," which Rodes calls "integral Christendom." This nexus was

characterized by a certain unity of purpose between church and state, an institutional symbiosis in which the church took responsibility for offering the state a Christian agenda for the whole society ..., and the state took responsibility for making the church's ministrations available to all citizens according to their several needs and desires. ${ }^{92}$

That world is gone, of course, and most people would say "good riddance!" 93 Rodes has proposed, though, that even after the dissolution of "integral Christendom," and even in the "state of affairs which people call pluralism," Christian church to accept and fulfill the "responsibility to offer an agenda to the wider society, and the responsibility for the spiritual development" of a wide range of people. ${ }^{95}$ Our situation today, then, is

genre, see Ross Douthat, Theocracy, Theocracy, Theocracy, First Things 30 (Aug./Sept. 2006).

88. See Rodes, Pluralist Christendom, supra n. 65.

89. Id at 413 ("The problem with which this article deals begins, like so many other problems, with the conversion of the emperor Constantine ....").

90. Id. at 414.

91. Id.

92. Id.

93. See e.g. Stanley Hauerwas, After Christendom? How the Church Is to Behave if Freedom, Justice, and a Christian Nation Are Bad Ideas (Abingdon Press 1991); Thomas L. Shaffer, Review Essay: Stephen Carter and Religion in America, 62 U. Cin. L. Rev. 1601, 16141615 (1994).

94. Rodes, Pluralist Christendom, supra n. 65, at 414.

95. Id. at 415. See also Rodes, supra n. 16, at 308 ("We are called as Christians not merely to survive in the world but to help redeem it."). 
called "pluralist Christendom" by Rodes. In this context, there is no longer a common religion-or even a common religious sense-but there is

still a concern with the familial quality of human society.... Within Christendom, there must be an aspiration to fraternal union among the citizens. It follows that government cannot be a mere umpire... in the struggle for survival.... It must give expression to a common desire for a fully human life for all. ${ }^{96}$

It is important to be clear here about what Rodes is not saying. He is not signing on to triumphalist versions of the America-as-a-ChristianNation thesis. He is not calling for a return of political or coercive power to religious authorities. He is not out to secure assistance from the state in enforcing specifically religious obligations and devotional duties. His point, instead, is much more prosaic. For Rodes, "Christendom" denotes the fact that our political community, along with several others, continues to be inhabited overwhelmingly by professing Christians. It might be easy for Christians to regard "governing the secular community" as a "dubious enterprise" but, nevertheless,

[i]n our society, ... Christians are still largely responsible for this dubious enterprise.... If they are not to relinquish this power and responsibility, they ought to exercise it with some understanding of who they are and whom they serve. ${ }^{97}$

It should also be emphasized that Rodes intends for the term "pluralist" to carry real meaning, and to have real bite. Our society is "pluralistic," period. "The basic trend of our society," he observes, "is to accommodate divergent views, not to suppress them." $" 98$ There are, in our state of affairs, a "multiplicity of religious or nonreligious commitments" and "a multiplicity or moral and social agendas." Although Christendom persists, we have, Rodes emphasizes,

people of many different views all around us, and even if we were not disposed to respect them, our religion itself would require us to do so. The question then becomes one of what agenda a Christian can offer for a society in which many people are not Christian. ${ }^{100}$

96. Rodes, Pluralist Christendom, supra n. 65, at 420.

97. Id. at 428.

98. Rodes, supra n. 21, at 690.

99. Rodes, Pluralist Christendom, supra n. 65 , at 414.

100. Id. at 416. See also id. at 427 ("[L]imiting the exercise of power and according freedom and respect to all human beings are not obstacles to the application of Christian principles; they are the application of Christian Principles."). 


\section{Dialogue and Freedom}

In the course of defending "pluralism" 101 as an alternative to "secularism," 102 Rodes has observed that opponents of the former regularly point to the "divisiveness" thought to be inherent in pluralistic structures and doctrines. ${ }^{103}$ This "divisiveness" provides, the opponents contend, a compelling reason for a general "privatization" of religion. To Rodes, however, it is "increasingly apparent that the privatization of religion is not a permanent solution to the problem raised by religious pluralism in Western society." no surprise. ${ }^{105}$

Rodes emphasizes not so much the persistence of disagreement and division as the fact that, notwithstanding the reality of pluralism, we continue to hold to a "national religious consensus" centered around two elements, which Rodes insists are "religious" elements: "dialogue" and "freedom." 106 The acknowledgment and support of this consensus, rather than a program of privatization, is, Rodes believes, the appropriate response to concerns about religious pluralism and "divisiveness." "Freedom," he has explained,

in our society, is an element of a national religious consensus in that it is conceived of as imposing on the efforts of organized society a limitation and a direction, both of which are derived from an essential insight into the spiritual nature of man. This essential insight is in some sense a religious one. ${ }^{107}$

The second element of this national religious consensus is "dialogue," which refers to "conversation among persons of different beliefs, having for its purpose mutual understanding and respect, rather than argument." 108 Like our commitment to "freedom," our commitment to dialogue is, Rodes believes, a religious one. After all, he has explained,

101. That is, "a division of society into separate religious 'communities,' each of which is recognized by the state as representing its adherents in all matters religious or related to religion." Rodes, Passing of Nonsectarianism, supra n. 66, at 118.

102. That is, the "confinement of the values endorsed by the state . . to those having to do with the world, or those not having to do with God." Id. at 117.

103. Id. at 119. See also id. at 120 ("This continues to be the theme of some of the most vigorous opposition to pluralistic solutions, particularly in the schools."); id. at 135 ("[T]he most telling objection to religious pluralism is that it is 'divisive'-i.e., that it is inconsistent with our national aspiration to fraternal union.").

104. Rodes, supra n. 15, at 879.

105. Rodes, Passing of Nonsectarianism, supra n. 66, at 131. Cf. e.g. Richard W. Garnett, Religion, Division, and the First Amendment, 94 Geo. L. J. 1667 (2006).

106. Rodes, Passing of Nonsectarianism, supra n. 66, at 134.

107. Id.

108. Id. 
[i]ts aspiration to personal rapport among persons of different religions is born of the recognition of a common spiritual nature and a common spiritual predicament. Its hope for such rapport lies in the recognition that God is a Person. ${ }^{109}$

Now, Rodes does not believe that we can simply extract from this consensus a neat body of doctrine or clear answers to all of our churchstate disputes. Instead, he sees these two principles-these two "religious elements" of our "national religious consensus"- not so much as "furnishing a logical basis for solving problems ... as conducing to an atmosphere in which they may be solved." 10

$[T]$ he value of freedom and dialogue as the root principles in our national religious consensus lies in their conformity on the one hand to what is deepest and truest in our traditional aspirations as a people, and on the other hand to a recognition of those central mysteries of human existence to which the most important of religious affirmations are addressed.

... The profoundest consequence of a national religious consensus worked out in terms of freedom and dialogue is that it becomes the concern of every citizen that every other citizen live out his own deepest commitments to the fullest possible extent. It is in this context of heightened spiritual awareness afforded by such a living out that we await the manifestation of divine power whereby freedom may be consummated in salvation, dialogue in unity. And it is in this concern for such a living out that we may hope for a solution to our immediate problems of church and state. ${ }^{11}$

\section{IV.}

I noted earlier Rodes's view that we in the United States have "not developed forms of [the High Church] kind"112 and that, in fact, "[t]he American legal structure has played a part in inhibiting the growth of High Church forms."113 One exception to this general observation, though, is the cluster of ecclesiastical-self-government or churchautonomy cases. ${ }^{114}$ Commenting on these cases, Rodes has observed that the "freedom of ecclesiastical processes to move in an area where

109. Id

110. Id. at 137.

111. Id.

112. Rodes, supra n. 57, at 305.

113. Id. at 306.

114. See e.g. Rodes, supra n. 57, at 307-317; Rodes, Pluralist Christendom, supra n. 65, at 419; Rodes, supra n. 21, at 689-690. 
secular processes cannot follow seems to be a High Church freedom."115 Indeed, "[this freedom] is less reminiscent of traditional Bill of Rights learning than of the medieval conception of libertas ecclesiae."116

"Libertas ecclesiae"- - the "Freedon of the Church"-was the rallying cry for Pope Gregory VII's eleventh-century campaign against the secular powers of the day for papal control over the Church, a "revolution" that, as the great legal scholar Harold Berman reports, worked nothing less than a "total transformation" of law, state, and society. ${ }^{117}$ I have suggested elsewhere that the preservation of the churches' moral and legal right to govern themselves in accord with their own norms and in response to their own calling is our day's most pressing religious freedom challenge. ${ }^{118}$ While it is settled that churches enjoy constitutionally protected freedoms to govern themselves and arrange their internal affairs in accord with religious teachings and authority, the scope and theoretical justification of these freedoms are unclear and contested, and the freedoms themselves are increasingly vulnerable. ${ }^{119}$ In case after case, and in all kinds of ways, the freedom and autonomy of religious communities today is challenged, even under attack. $^{120}$ Whether the dispute involves the supervision of diocesan finances by a bankruptcy court or administrative agency, a requirement that religiously affiliated organizations pay for employees' contraception, a challenge to religious schools' decisions about the hiring and firing of teachers, or the usurpation by China's government of the Catholic Church's ancient right to select bishops, it seems that the church-autonomy question-and not the words of the Pledge of Allegiance, or public displays of crosses on hilltops and the Ten Commandments in parks-is the front line.

This vulnerability is connected, no doubt, to the limited, and dwindling, appeal in public discourse of "church autonomy." We are, generally speaking, enthusiastic about autonomy, of course, but many of us are uneasy about connecting "church" with nomos. Matters are not helped by the fact that the idea is often understood as entailing the

115. Rodes, supra n. $\mathbf{5 7}$, at 317.

116. Id.

117. Harold J. Berman, Law and Revolution: The Formation of the Western Legal Tradition 23 (Harv. U. Press 1983); see also supra n. 7, at 11-14 (discussing the "papal revolution").

118. See e.g. Richard W. Garnett, Church, State, and the Practice of Love, Vill. L. Rev. (forthcoming 2007); Garnett, supra n. 29.

119. See generally e.g. Mark E. Chopko \& Michael F. Moses, Freedom to Be a Church: Confronting Challenges to the Right of Church Autonomy, 3 Geo. J. L. \& Pub. Policy 387 (2005).

120. See e.g. Diana B. Henriques, Where Faith Abides, Employees Have Few Rights, N.Y. Times A1 (Oct. 9, 2006). 
assertion that clergy and church employees are entirely "above the law" and unaccountable for wrongs they do or harms they cause. ${ }^{121}$ And, the freedom of religious associations, communities, and institutions is made more vulnerable by the link that many perceive between church autonomy principles, on the one hand, and-on the other-sexual abuse by clergy, venality and mismanagement by bishops, and diocesan declarations of bankruptcy. ${ }^{122}$ To the extent the church autonomy principle is thought to privilege institutions over individuals, or structures over believers, its appeal will suffer. After all, people today tend to think about faith-and, by extension, religious freedom-more in terms of personal spirituality than of institutional affiliation, public worship, and tradition. ${ }^{123} \mathrm{We}$ are-many of us, anyway-like the woman, Sheila Larson, described by Robert Bellah and his colleagues in The Habits of the Heart, who described her faith as "Sheilaism." "224 To the extent we approach religious faith as a form of self-expression, performance art, or therapy, we are likely to regard religious institutions as at best potentially useful vehicles or tools or, more likely, as stifling constraints or bothersome obstacles to self-discovery.

Nevertheless, churches' freedom-that is, their independence from political control over their internal polity and norms-is a vital dimension of any attractive notion of religious freedom. As John Courtney Murray put it, the independence and freedom of the church long furnished a "social armature to the sacred order," within which the human person would be "secure in all the freedoms that his sacredness demands." 125 He insisted that we are not really free if "[our] basic human things are not sacredly immune from profanation by the power of the state"126 and contended that it was libertas ecclesiae that supplied the

121. See e.g. Marci A. Hamilton, God vs. the Gavel: Religion and the Rule of Law 8 (Cambridge U. Press, 2005) (contending that "[i]n recent decades, religious entities have worked hard to immunize their actions from the law" and "lobbying for the right to hurt others without consequences"). See also e.g. Kathleen A. Brady, Religious Group Autonomy: Further Reflections About What Is at Stake 6-7 (working paper, on file with author).

122. See e.g. Marci Hamilton, The Catholic Church and the Clergy-Abuse Scandal: Act Three, http://writ.news.findlaw.com/hamilton/20030410.html, Apr. 10, 2003 (arguing that "the so-called church autonomy doctrine is not really a legal doctrine at all, at least as far as the U.S. Constitution and Supreme Court are concerned. Rather, it is an insidious theory that invites religious licentiousness rather than civic responsibility.").

123. See generally Richard W. Garnett, Assimilation, Toleration, and the State's Interest in the Development of Religious Doctrine, 51 UCLA L. Rev. 1645, 1662-1665 (2004). See also e.g. William Dinges et al., A Faith Loosely Held: The Institutional Allegiance of Young Catholics, 125 Commonweal 13 (July 17, 1998).

124. See Robert N. Bellah et al., Habits of the Heart: Individualism and Commitment in American Life 221, 235 (U. Cal. Press 1996).

125. Murray, supra n. 20, at 204-205.

126. Id. at 204 . 
limiting principle that could "check the encroachments of secular power and preserve these immunities." 27 If churches are not independent of the state, if they are not free to be different from the state, and if the government is not limited by churches' freedom, then believers are not free-not really free-either. ${ }^{128}$

Returning, then, to Rodes's observation that "[ $t]$ he American legal structure has played a part in inhibiting the growth of High Church forms," ${ }^{129}$ it strikes me that, in the same vein, we might well worry that there is not, in American constitutional law, a well-founded commitment to-or even room for--something like the libertas ecclesiae principle. This is not to say, of course, that the First Amendment does not provide meaningful protections for religious freedom. And, certainly, there are various constitutional doctrines and lines of cases that, in effect, guard the church's - or, more accurately, churches'-ability and right to control their internal structure and operations, to propose their own messages, to administer their own sacraments, and to conduct their own liturgies. Nevertheless, as Professor Gerard Bradley has observed, the idea of "church autonomy" sits uneasily in our law and discourse about religious freedom, because of our "longstanding blind spot... concerning groups of all kinds. Liberalism," he continued, "adeptly reasons about the individual and the state, but cannot fathom groups." "30

For Rodes, the relative paucity of High Church forms in American law and life is a cause for concern, and not simply because it might put religious institutions in a vulnerable litigation posture. In his view, our "basically Erastian church-state nexus" is the worse off for lacking a "relevant and effective institutional High Church witness." 131 High Church institutions, he has suggested, are necessary in order to "stand witness to the transcendent sovereignty of God," to "proclaim the judgment of God," and to offer a "refuge ... from a kind of servitude to the world and its concerns." "132 In addition, though-and perhaps more prosaically - it would seem that authentic freedom of religion does not exist when its manifestation in and expression through the life of non-

127. Id.

128. Gerard V. Bradley, Church Autonomy in the Constitutional Order: The End of Church and State?, 49 La. L. Rev. 1057, 1061 (1989) (contending that "church autonomy" is the "flagship issue of church and state," the "litmus test of a regime's commitment to genuine spiritual freedom").

129. Rodes, supra n. 57 , at 306.

130. Bradley, supra n. 128, at 1064.

131. Rodes, supra n. 57, at 307. See also id. at 336 (noting that the lack of "an institutional High Church witness" is "a serious defect in our national life").

132. Id. at 337-338. 
state institutions and communities is inhibited-that is, when High Church institutions and forms are not able to "provide[] the state with a limit and the church with a critique"133 -and also, more generally, that independence for such institutions and communities is both a feature of and a necessary condition for political freedom. In a free society, such forms, and something like libertas ecclesiae, will serve as structural features of social and political life, and will contribute to the development and sustaining of constitutionally limited government. Increasingly, though, independent churches are regarded as dangerous centers of potentially oppressive power, as in need of supervision and regulation by the state in its capacity as protector of individual liberty and conscience. ${ }^{134}$ In Murray's words, the "prophets of modernity" regard the freedom of the church "as a trespass upon, and a danger to, their one supreme value - the "integrity of the political order." 135 And so, Professor Rodes's exposition and defense of High Church forms, therefore, and his reminder that "[b]y operating outside the practical limits of power, [the church] witnesses those limits[,]"136 remain important, and welcome.

$$
\text { V. }
$$

I am confident that no one who has been blessed with the chance to know Professor Rodes and his work is surprised to learn that this inspiringly humane scholar has, for more than fifty years, been politely but powerfully questioning "wall of separation" talk for its failure to speak to the "real needs of real people." "137 As I have describedincompletely, of course-he has presumed and presented a church-state "nexus"; asked about the role of law, and the task of Christians in constructing and living in it; and invited fellow citizens of good will to converse about its implications. As he wrote:

[T]he church-state nexus I have envisioned is not one free from conflict, or one with all the problems worked out. It has built-in

133. Id. at 336. See also Murray, supra n. 20, at 204-205 (arguing that the "freedom of the Church ... served as the limiting principle of the power of government"). See generally Garnett, supra n. 29.

134. See generally e.g. Hamilton, supra n. 120. But see e.g. Declaration on Religious Freedom, in The Documents of Vatican II 675, 694 (Walter M. Abbot ed., Joseph Gallagher, trans. 1965) (available at http://www.ewtn.com/library/COUNCILS/v2relfre.htm) ("[A] harmony exists between the freedom of the Church and the religious freedom which is recognized as the right of all men and communities and sanctioned by constitutional law.").

135. Murray, supra n. 20, at 207.

136. Rodes, Pilgrim Law, supra n. 11, at 169.

137. See Rodes, Pluralist Christendom, supra n. 65, at 426. 
potentialities for tension, frustration, or even heartbreak, as any human situation has. It might be a situation, though, in which the Word of God can break forth in its own way, or at least a situation in which a Christian could live by his own best understanding of the Gospel, and do such work and bear such witness as God has called him to. This is perhaps all we can hope for from institutional patterns in this world.

Through his life, teaching, and scholarship, Professor Rodes has been not just an example, but an exemplar, of how a Christian can "do such work and bear such witness."

138. Rodes, supra n. 57, at 348 (footnote omitted). 
. 